\title{
Influence of weather variables on the development of pearl millet downy mildew
}

\author{
ASHLESHAATRI ${ }^{*}$ and HARPREET SINGH ${ }^{2}$ \\ ${ }^{1}$ Department of Plant Breeding and Genetics, ${ }^{2}$ Department of Climate Change and Agricultural Meteorology, \\ Punjab Agricultural University, Ludhiana - 141004 \\ Email: ashlesha-atri@pau.edu
}

\begin{abstract}
The present study was undertaken during 2016 to 2018 to find out the effect of different weather variables on the initiation and development of downy mildew in pearl millet in Punjab. The maximum temperature ranged from $32.8^{\circ} \mathrm{C}$ to $36.9^{\circ} \mathrm{C}$ and minimum temperature ranged from $17.2^{\circ} \mathrm{C}$ to $27.8^{\circ} \mathrm{C}$ during the crop season. The correlation analysis showed significant negative correlation of maximum temperature $\left(r=-0.665^{*}\right)$, minimum temperature $\left(r=-0.776^{* *}\right)$, wind speed $\left(r=-0.898^{* *}\right)$, rainfall $(r=-$ $\left.0.625^{* *}\right)$ and non-significant negative correlation of evening relative humidity $(r=-0.523)$ with downy mildew incidence. The positive correlation with morning relative humidity $\left(r=0.871^{* *}\right)$ was significant and sunshine hours $(r=0.321)$ were non-significant with per cent disease incidence. A multiple regression model was developed using two years (2016 and 2017) data to predict the occurrence of downy mildew with $R^{2}=0.981$, indicating that all weather parameters contributed 98.1 per cent towards disease development. The model was validated with 2018 data which shows that equation can be used in the disease forecasting for taking timely actions for control measures.
\end{abstract}

Keywords: Downy mildew, pearl millet, Sclerospora graminicola, disease incidence, weather variables

Pearl millet is a major cereal and fodder crop grown all over the world and in India. It is grown in 7.13 million hectares area with 8.06 million tons of annual production (Anonymous, 2017). Downy mildew is one of the major constraints in the growth and development of pearl millet and appears every year in all pearl millet growing areas. Downy mildew is an oomycetous fungus caused by Sclerospora graminicola (Sacc.) J. Schröet causes huge losses to the crop up to the tune of 40-60 per cent (Hash et al., 2003). S. graminicola, causing downy mildew is very serious disease in all pearl millet growing areas and it causes huge losses to growers in terms of yield and reduces its market value. Environmental factors like temperature, rainfall, relative humidity, wind, dew, cloudiness and duration, quality and intensity of radiation play an important role in the development and spread of downy mildew (Gupta and Singh, 2000). Host, environment, edaphic and biotic factors influence the processes involved in disease cycle of pathogen, which ultimately determine the level of infection. A good deal of work has been done on the influence of temperature and relative humidity on the development of downy mildew in other states (Singh and Gopinath, 1990), but relatively limited studies have been conducted on the influence of these environmental factors on downy mildew especially in pearl millet growing areas of Punjab. Therefore, analysis of weather parameters provides a base to take preemptive decision against the disease under a given set of environmental conditions for better management practices. Keeping these points in view, the present study was undertaken to study the effect of weather variables on the initiation and temporal progression of downymildew disease, develop regression equations for predicting outbreak and determine most appropriate management measures to control downy mildew effectively.

\section{MATERIALS AND METHODS}

Field trials were conducted to find out the effect of weather parameters on downy mildew in pearl millet during two consecutive Kharif seasons in 2016 and 2017 at Forage and Millet Farm, PAU, Ludhiana $\left(30^{\circ} 56^{\prime} \mathrm{N}\right.$ latitude and $75^{\circ} 52^{\prime}$ E longitude with an elevation of $247 \mathrm{~m}$ above mean sea level), Punjab. Highly susceptible cultivar $7042 \mathrm{~S}$ was sown in rows following recommended agronomic practices. The distance between row to row and plant to plant was 50 and $10 \mathrm{~cm}$ respectively. The experiment was laid out in a complete randomized block design (RBD) with three replications in the sick plot which has been maintained by frequent addition of dried and infected pearl millet plants in every season for the source of inoculum of $S$. graminicola. Soil borne inoculum of downy mildew served as source of primary infection in pearl millet plants. Plots of pearl millet were 
Table 1: Effect of different environmental factors on the development of downy mildew (Pooled data of 2016 and 2017)

\begin{tabular}{|c|c|c|c|c|c|c|c|c|}
\hline \multirow{2}{*}{$\begin{array}{l}\text { Standard } \\
\text { week }\end{array}$} & \multirow{2}{*}{$\begin{array}{c}\text { Percent } \\
\text { Disease } \\
\text { Incidence }\end{array}$} & \multicolumn{2}{|c|}{ Temperature $\left({ }^{\circ} \mathrm{C}\right)$} & \multicolumn{2}{|c|}{ Relative humidity (\%) } & \multirow{2}{*}{$\begin{array}{c}\text { Rainfall } \\
(\mathrm{mm}) \\
\mathrm{day}^{-1}\end{array}$} & \multirow{2}{*}{$\begin{array}{c}\text { Sunshine } \\
\text { hours } \\
\left(\mathrm{kmh}^{-1}\right)\end{array}$} & \multirow{2}{*}{$\begin{array}{l}\text { Wind } \\
\text { speed }\end{array}$} \\
\hline & & Maximum & Minimum & Morning & Evening & & & \\
\hline 28 & 5.1 & 36.2 & 27.2 & 73.5 & 53.0 & 36.5 & 6.4 & 5.1 \\
\hline 29 & 9.6 & 36.9 & 26.6 & 73.0 & 48.5 & 48.9 & 6.8 & 3.7 \\
\hline 30 & 13.3 & 33.8 & 26.3 & 83.0 & 66.0 & 58.7 & 5.8 & 5.8 \\
\hline 31 & 17.1 & 34.8 & 27.8 & 77.5 & 59.0 & 5.6 & 5.1 & 4.7 \\
\hline 32 & 20.8 & 33.3 & 27.7 & 81.0 & 64.0 & 16.5 & 4.2 & 4.2 \\
\hline 33 & 24.1 & 34.2 & 27.0 & 82.0 & 61.0 & 32.4 & 7.9 & 2.8 \\
\hline 34 & 26.8 & 32.8 & 26.0 & 86.0 & 69.5 & 32.9 & 5.9 & 3.6 \\
\hline 35 & 30.1 & 33.6 & 26.4 & 85.0 & 66.5 & 3.0 & 6.1 & 3.9 \\
\hline 36 & 33.0 & 34.6 & 26.8 & 83.5 & 58.5 & 7.5 & 9.5 & 2.2 \\
\hline 37 & 35.5 & 33.8 & 25.6 & 84.5 & 59.0 & 5.8 & 8.8 & 2.4 \\
\hline 38 & 38.0 & 33.1 & 25.7 & 84.5 & 63.5 & 51.2 & 5.4 & 2.4 \\
\hline 39 & 41.6 & 33.5 & 24.7 & 84.5 & 59.5 & 7.5 & 5.0 & 2.0 \\
\hline 40 & 43.1 & 34.4 & 22.9 & 88.3 & 46.3 & 0.0 & 6.6 & 1.8 \\
\hline 41 & 45.0 & 33.8 & 20.4 & 90.0 & 39.0 & 0.0 & 8.1 & 1.6 \\
\hline 42 & 45.3 & 33.8 & 17.2 & 87.5 & 32.0 & 0.0 & 8.3 & 1.3 \\
\hline
\end{tabular}

irrigated when necessary.

Downy mildew incidence was recorded with the appearance of typical symptoms of downy mildew at weekly interval. The incidence of downy mildew was computed as the percentage of diseased plants over the total number of plants in each plot. This was calculated using the following formula(Ball, 1983):

$$
\mathrm{PDI}=\frac{\mathrm{n}}{\mathrm{N}} \times 100
$$

Where, $\mathrm{PDI}$ is per cent disease incidence, $\mathrm{N}$ is total number of observed plants, $\mathrm{n}$ is total number of diseased plants.

Observations on the appearance and progress of downy mildew in pearl millet were recorded at weekly intervals starting with the onset of disease until the occurrence of maximum disease incidence. The weather data like maximum and minimum temperatures, morning and evening relative humidity, rainfall, sunshine hours per day and daily wind speed in $\mathrm{km} \mathrm{h}^{-1}$ were recorded from School of Climate Change and Agricultural Meteorology, PAU, Ludhiana for the period of experimentation.

The influence of each weather parameter on downy mildew disease in pearl millet was determined by multiple regression analysis. Regression equations were worked out to find out the most critical weather parameter contributing occurrence of downy mildew disease by considering all the weather parameters as independent variables and disease incidence as dependent variable. All data analysis was carried out using SPSS software.

\section{RESULTS AND DISCUSSION}

The weekly mean values of weather parameters and Per cent disease incidence (PDI) are presented in Table 1. It is evident that downy mildew incidence was observed from $28^{\text {th }}$ to $42^{\text {nd }}$ standard meteorological week (SMW) in both the cropping seasons (Table1). During this period, average maximum and minimum temperature range was $32.8^{\circ} \mathrm{C}$ to $36.9^{\circ} \mathrm{C}$ and $17.2^{\circ} \mathrm{C}$ to $27.8^{\circ} \mathrm{C}$ respectively with more than 73 per cent of morning relative humidity. Total rainfall of 306.6 $\mathrm{mm}$ was received which favoured the disease development and spread.

Disease incidence was observed during second week of July in the field and increased gradually upto the last week of October during both the years. Average disease incidence was 5.1 per cent in $28^{\text {th }} \mathrm{SMW}$, it increased significantly and reached upto 45.3 per cent during $42^{\text {nd }}$ SMW during the cropping season when maximum 


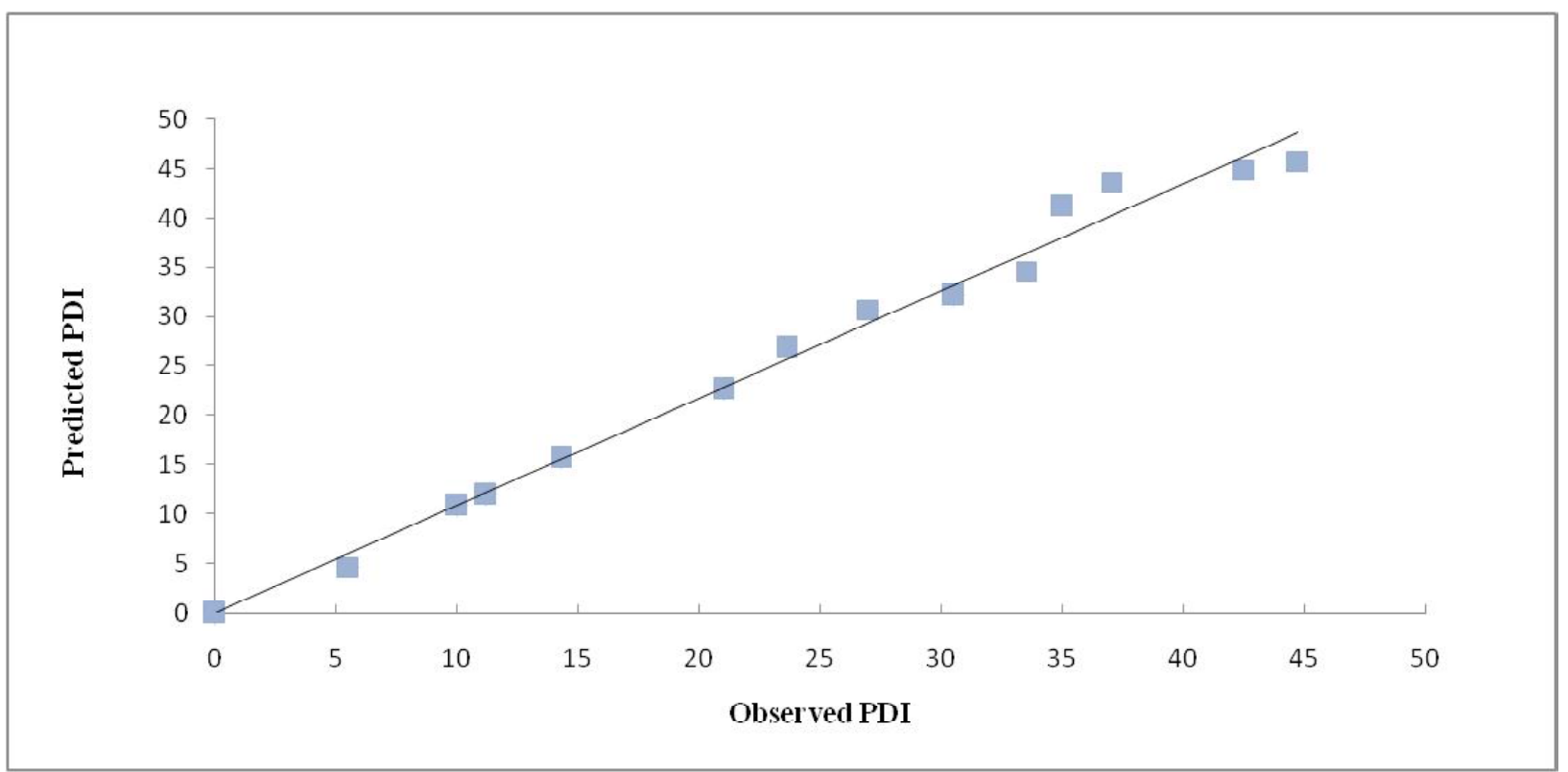

Fig. 1: A comparison of observed and predicted PDI values

Table 2: Correlation co-efficient(r) between weather factors and per cent diseases incidence

\begin{tabular}{ll}
\hline Weather variables & Correlation co-efficient $(\mathrm{r})$ \\
\hline Maximum temperature & $-0.665^{*}$ \\
Minimum temperature & $-0.776^{* *}$ \\
Morning relative humidity & $0.871^{* *}$ \\
Evening relative humidity & $-0.523^{\mathrm{NS}}$ \\
Rainfall & $-0.625^{* *}$ \\
Sunshine hours & $0.321^{\mathrm{NS}}$ \\
Wind speed & $-0.898^{* *}$ \\
\hline
\end{tabular}

*Significant at $5 \%$ level, ** Significant at $1 \%$ level

temperature was $33.8^{\circ} \mathrm{C}$. During $28^{\text {th }}$ and $29^{\text {th }}$ SMWs, 36.5 and $48.9 \mathrm{~mm}$ rainfall favoured the disease initiation and development (Table 1). Increase in number of sunshine hours from 5.0 to 9.5 , favoured the disease progression.

\section{Correlation analysis}

Correlation coefficients between weather parameters and downy mildew incidence over the two seasons were worked out Table 1 . The results revealed that a negative and significant correlation $\left(r=-0.665^{*}\right)$ between maximum temperature and PDI was observed. Similarly, minimum temperature also showed a negative but significant correlation $\left(\mathrm{r}=-0.776^{* *}\right)$ with PDI as it decreased from $27.8^{\circ} \mathrm{C}$ to $17.2^{\circ} \mathrm{C}$ with the progress of disease incidence. Total rainfall had a negative and significant correlation $(\mathrm{r}=$ $-0.625 * *$ ) with PDI.
A significant positive correlation of morning relative humidity $\left(\mathrm{r}=0.871^{* *}\right)$ was found with PDI. Average relative humidity was 73.5 per cent at the time of disease initiation and then it increased gradually to 90.0 per cent with the disease progression. Evening relative humidity was found negatively correlated and non-significant $(r=-0.523)$ with PDI. It was 53.0 per cent at the start of the disease and after that it decreased to 32.0 per cent with the commencement of PDI upto $42^{\text {nd }}$ SMW. So, the morning relative humidity contributed to the development and spread of disease. A positive and non-significant correlation was observed between sunshine hours and downy mildew incidence $(r=$ $0.321^{\mathrm{NS}}$ ) (Table 2). Wind speed had a negative and significant correlation $\left(\mathrm{r}=-0.898^{* *}\right)$ with PDI which implies that it contributed less in disease progression as decrease in wind speed from $28^{\text {th }}$ to $42^{\text {nd }}$ SMW was observed with advancement of disease incidence. These results are confirmed by the findings of Daunde et al. (2017) who have reported increment in downy mildew disease of cucumber from $28^{\text {th }}$ SMW to $39^{\text {th }}$ SMW with high morning relative humidity ( $96 \%$ ), evening relative humidity $(84 \%)$ and variation in maximum and minimum temperature from $27.9^{\circ} \mathrm{C}$ to $34.4^{\circ} \mathrm{C}$ and $18.4^{\circ} \mathrm{C}$ to $21.5^{\circ} \mathrm{C}$ respectively.

\section{Multiple regression analysis}

A multiple regression model was developed to predict the occurrence of downy mildew. The best fit regression model for disease is as under

$\mathrm{Y}=-17.293+0.210 \mathrm{X}_{1}-0.974 \mathrm{X}_{2}+0.928 \mathrm{X}_{3}+0.250 \mathrm{X}_{4}-0.084 \mathrm{X}_{5}$ $-1.046 \mathrm{X}_{6}-5.976 \mathrm{X}_{7}$ with $\mathrm{R}^{2}=0.981$, 
where, $\mathrm{Y}=$ Percent disease incidence, $\mathrm{X}_{1}=$ Maximum temperature $\left({ }^{\circ} \mathrm{C}\right), \mathrm{X}_{2}=$ Minimum temperature $\left({ }^{\circ} \mathrm{C}\right), \mathrm{X}_{3}=$ Morning relative humidity (\%), $\mathrm{X}_{4}=$ Evening relative humidity $(\%), X_{5}=$ Total rainfall $(\mathrm{mm}), X_{6}=$ Sunshine hours/ day, $\mathrm{X}_{7}=$ Wind speed $\left(\mathrm{kmh}^{-1}\right)$.

The results of multiple regression model exhibited a positive correlation of downy mildew incidence with maximum temperature, morning and evening relative humidity and negative correlation with other weather parameters. The value of coefficient of determination $\left(\mathrm{R}^{2}=\right.$ 0.981 ) indicated that all weather parameters contributed 98.1 per cent towards disease development. From the given multiple regression model, it is evident that major factors responsible for disease development are maximum temperature, morning and evening relative humidity along with intermittent rainfall and increase in sunshine hours. This implies that with one unit change in maximum temperature, morning and evening relative humidity, there would be probable change of $0.210,0.928$ and 0.250 units in downy mildew incidence respectively.

\section{Model validation}

The model so developed based on two years data (2016-2017) was validated with the data of year 2018. It was observed that the slope of predicted and observed values of PDI was linear (Fig. 1).

Our results are in support of earlier findings of Bose et al. (2010) who reported that maximum temperature was positively and significantly related to the development of downy mildew disease in pearl millet. Similar to our findings, Kumar et. al., (2010) revealed that mean temperature, wind speed and growing-degree-day collectively showed up to 72 per cent variability in progress of downy mildew disease in pearl millet. The statistical models described the variability in downy mildew incidence in grapes to the extent of 89.4 per cent due to maximum temperature, evaporation and relative humidity (Vijay et al., 2013).

\section{CONCLUSIONS}

It can be concluded that weather variables play an important role in the initiation and progression of downy mildew in pearl millet. The maximum temperature $\left(32.8^{\circ} \mathrm{C}\right.$ to $36.9^{\circ} \mathrm{C}$ ), minimum temperature $\left(17.2^{\circ} \mathrm{C}\right.$ to $\left.27.8^{\circ} \mathrm{C}\right)$ and relative humidity of more than 73 per cent are considered as crucial weather factors which favoured the disease development. The model developed would be useful in forecasting of downy mildew disease for devising suitable management strategy.

\section{ACKNOWLEDGMENTS}

Authors thank the Head of the Department of Plant Breeding and Genetics, PAU, Ludhiana for providing financial assistance and all laboratory and outdoor facilities.

\section{REFERENCES}

Anonymous. (2017). India Agristat2017, https://jgateplus.com.

Ball, S.L. (1983). Pathogenic variability of downy mildew (Sclerospora graminicola) on pearlmillet. I. Host cultivar reactions to different pathogen isolates. Ann. Appl. Biol., 102: 257-264.

Bose, S., Niwas, R., Kumar, A., Khichar, M. L. and Mani, J.K. (2010). Effect of agrometeorological parameters on incidence of downy mildew in pearl millet. $J$. Agrometeorol., 12(1): 133-135.

Daunde, A.T., Magar, S.P. and Navgire, K.D. (2017). Correlation of weather factors with downy mildew of cucumber. Agric. Update, 12(TECHSEAR-1): 105-108; DOI: 10.15740/HAS/AU/ 12.TECHSEAR(1)2017/105-108.

Gupta, G.K. and Singh, D. (2000). Epidemiological studies on downy mildew of pearl millet (Pennisetum glaucum). Intern. J. Tropical Plant Dis., 18:101-115.

Hash, C.T., Yadav, R.S., Sharma, A., Bidinger, F.R., Devos, K.M., and Gale, M.D. (2003). Pearl millet molecular marker research. PSP Ann. Rep., 35: 23-56.

Kumar,A., Niwas, R., Kumar,A., Pawar, M.S. and Khichar,M.L. (2010). Regression models for prediction of downy mildew progression in pearl millet var HB 3 based on weather parameter. J. Agrometeorol., 12(1): 92-96.

Singh, S.D. and Gopinath, R. (1990). Effect of temperature and light on sporangial germination and zoospore infectivity in Sclerospora graminicola on pearl millet. Can. J. Plant Pathol., 12: 25-30.

Vijay, N., Venugopalan, R., and Srinivasaraghavan, A. (2013). Association among weather parameters and incidence of downy mildew in grapes. BIOINFOLET - A Quart.J. Life Sci., 10(3a): 804-807. 